\title{
Aplicação do Índice de Concentraçãa de Rugosidade (ICR) para análise de ba- cias hidrográficas e para traçado de lineamentos estruturais
}

\section{Application of Roughness Concentration Index (RCI) for analysis of watershed and mapping of structural lineaments}

Diego Moraes Flores *

Déborah de Oliveira**

\section{Resumo:}

O presente trabalho aplicou o índice ICR (índice de concentração de rugosidade) em três bacias hidrográficas (bacias dos rios Coutinho, Maracujá e Campo Real), localizadas no município de Guarapuava, no centro sul do Estado do Paraná. O ICR se mostrou uma técnica adequada para identificação da dissecação do relevo, pois identificou com precisão as zonas de grande interferência tectônica, a partir dos lineamentos traçados, demonstrando as áreas com maior e menor incisão fluvial. Além disso, a visualização das zonas de intensidade de ICR facilitou uma interpretação geral da disposição das morfologias que compõem o relevo, sejam elas ligadas direta ou indiretamente às zonas de falha e fratura.

\footnotetext{
Abstract:

This work applied the index RCI (roughness concentration index) in three watersheds (rivers basins of Coutinho, Maracujá and Campo Real), located in Guarapuava, in Parana state southern center. The RCI proved to be a suitable technique for the identification of relief dissection because identified with accuracy the areas of high tectonic interference as from strokes lineaments, showing areas with higher and lower river incision. Moreover, the display of the ICR intensity zones facilitated a general understanding of the morphologies arrangement that form the relief, connected directly or indirectly to the failure and fracture zones
}

* Doutorando do Programa de Pós Graduação em Geografia Física da Faculdade de Filosofia, Letras e Ciências Humanas - FFLCH-USP

** Profa. Dra. do Departamento de Geografia da Faculdade de Filosofia, Letras e Ciências Humanas - FFL$\mathrm{CH} / \mathrm{USP}$
Palavras-chave:

Lineamentos estruturais, Bacia hidrográfica, ICR

Key-Words: Structural lineaments, Watershed, RCI 


\section{INTRODUÇÃO}

Dara a identificação de unidades homogêneas do
relevo, uma técnica estabelecida por SAMPAIO (2008), utiliza-se do processamento matemático dos pixels contidos em um MDE (modelo digital de elevação) para o levantamento quantitativo do formato das vertentes e, sobretudo dissecação do relevo. A metodologia baseia-se na análise das curvaturas verticais e horizontais das vertentes para classificação morfométrica do relevo, (ZUQUETTE e GANDOLFI, 2004; VALERIANO 2008; SAMPAIO e AUGUSTIN, 2014a).

Sampaio (2008) e Sampaio e Augustin, (2014b), aplicaram a referida metodologia de classificação morfométrica, idealizada conceitualmente por Horton (1945) e Hobson (1972), obtendo valores que representam as unidades homogêneas de um dado relevo e de sua dissecação. A técnica, segundo os autores, (op. cit.) possibilita a identificação de unidades geomorfológicas homogêneas a partir de padrões morfométricos de dissecação e dados de declividade, sendo denominada por Sampaio (2008) de Índice de Concentração de Rugosidade (ICR).

A referida técnica auxilia pesquisas geomorfológicas utilizando-se de modelos matemáticos e estatísticos, nos quais o relevo é tomado como uma variável numérica, permitindo o manuseio e tratamento de imagens de radar em softwares de diversos tipos. Outra característica importante da metodologia é a possibilidade de menor subjetividade, pois permite uma leitura tridimensional dos fatos geomorfológicos, a partir de uma classificação morfométrica do relevo.

Segundo Sampaio e Augustin, (2014b) a área de 1 $\mathrm{km} 2$ pode ser usada como unidade espacial mínima central, atribuída aos pixels da imagem de radar, na identificação de unidades geomorfológicas homogêneas em relação aos padrões morfométricos de dissecação.

Sampaio (2008) delimitou uma forma padrão de variabilidade dos valores altimétricos das vertentes e de seus segmentos, através dos valores de declividade, nos quais, o uso de ferramentas de softwares de mapeamento possibilita a transformação de pontos com conotação numérica em informações topológicas. Estes, uma vez, combinados novamente como valores de intensidade zonal e tratados pelas ferramentas de mapeamento dos softwares permitem a obtenção do índice de concentração de rugosidade do relevo (ICR).

A compartimentação do relevo pela técnica é for- necida pelo padrão espacial regional da rugosidade do relevo em área localmente acidentadas (onduladas) ou planas, identificando as unidades morfologicamente homogêneas a partir da dissecação, para áreas de grandezas distintas, em escalas diferentes e com o uso de materiais cartográficos de base, tendo como requisito chave, um modelo digital de elevação.

Neste trabalho aplicou-se o índice de rugosidade do relevo sobre três bacias hidrográficas localizadas no município de Guarapuava (PR). A finalidade foi demonstrar a utilização do índice e obter a compartimentação do relevo a fim de facilitar a delimitação de lineamentos estruturais existentes na região das bacias hidrográficas.

Entende-se que o uso desta técnica, possibilita identificar feições morfológicas ligadas às interferências tectônicas, das quais serão relevantes para uma interpretação do relevo e da rede de drenagem. A observação da compartimentação do relevo oriundo do uso do ICR permite a observação das zonas onde a rugosidade é maior, e uma vez combinado, com os lineamentos traçados sobre as bacias hidrográficas facilitaria a inferência de como a tectônica interfere sobre a drenagem.

Sabe-se que as zonas de interferência tectônica sobre litologias diversas promovem a formação de convexidades e concavidades (LIMA, 2009, 2010, 2014) em trechos dos perfis longitudinais a depender de sua disposição sobre a rede de drenagem. O trabalho erosivo dos rios, sobre trechos com interferência dos lineamentos podem expor litologias com características estruturais distintas, possibilitando assim, uma interpretação sobre a resistência diferencial das litologias aflorantes e consequentemente fornecendo indagações sobre a resposta geomorfológica fornecida pela relação tectônica-rede de drenagem.

Acredita-se, que o uso de dados de origem numérica, como o MDE (modelo digital de elevação), aliado ao uso da técnica do ICR, possa fornecer uma observação adequada do padrão de dissecação e compartimentação do relevo.

\section{1. ÁREA DE ESTUDO}

A área de estudo se localiza no município de Guarapuava e porções limítrofes de municípios vizinhos a norte e oeste deste. As bacias hidrográficas (Fig.1) foco do trabalho são: as bacias dos rios Campo Real, Coutinho e Maracujá, este último, afluente principal da margem direita do Coutinho. 
Juntas as bacias possuem aproximadamente, 909,138 km2 de área, localizadas a oeste de Curitiba, mais precisamente no Terceiro Planalto paranaense. Dista a aproximadamente $255 \mathrm{~km}$ da capital do estado. O principal acesso por leste/oeste se dá pela BR-277, e norte/sul o acesso é pela PR 170 (BR 466).
cesystems.or.jp/ersdac/GDEM/E/index.html).

Os passos realizados com o uso do software de mapeamento podem também ser elaborados em outros aplicativos, como os softwares livres QGIS e SPRING.

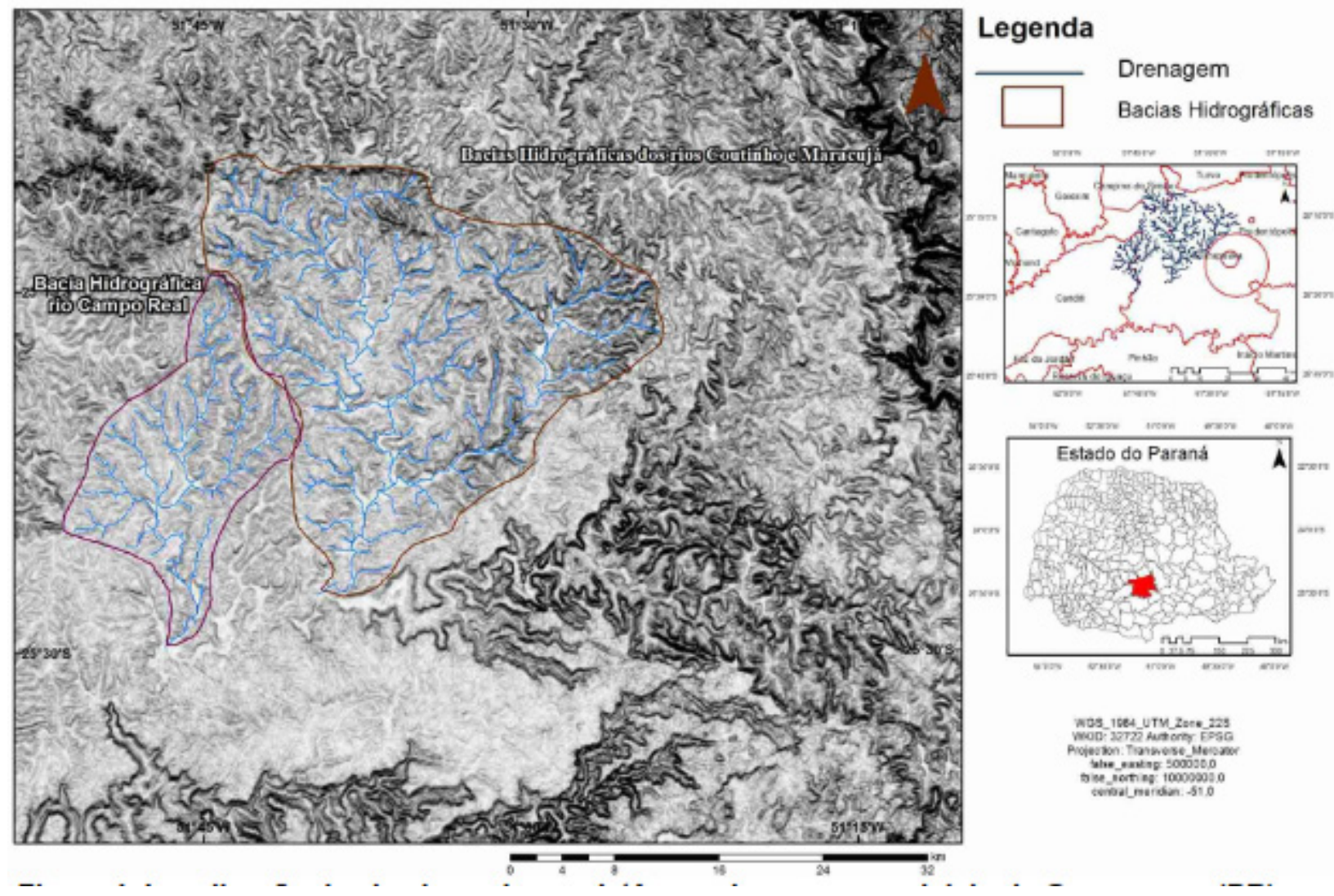

Figura 1. Localização das bacias sobre o platô que abrange o município de Guarapuava (PR) e municípios vizinhos. Fonte: Org. autores.

\section{MATERIAIS E MÉTODOS}

Para a obtenção do índice de rugosidade do relevo (ICR) é necessário à confecção de uma base cartográfica. Neste sentido, foi utilizado o software de mapeamento Arc Gis 10, para a elaboração das curvas de nível, drenagem e demais produtos cartográficos. A licença utilizada do software foi a temporária disponibilizada pela empresa comercializadora durante o período de 60 dias (free trial). Optou-se por imagem de radar referente ao projeto ASTER GDEM com resolução de 30 metros disponibilizada gratuitamente no endereço eletrônico:

(http://gdex.cr.usgs.gov/gdex/;http://www.jspa-
Mudando-se em cada programa, apenas a suíte de ferramentas, os procedimentos e a nomenclatura das ferramentas destinadas à confecção dos mapas. A seguir seguem-se os procedimentos metodológicos para a elaboração dos mapas de ICR, declividade e traçado de lineamentos:

\subsection{Coordenadas e curvas de nível}

Para estabelecer as coordenadas planas e geográficas para as bacias hidrográficas, seguiram-se os seguintes passos:

- Com um click do botão direito sobre o frame (símbolo de camadas no canto superior esquerda da ja- 
nela table of contentes), selecionou-se na sequência a opção properties, no item coordinate system, inseriu-se como projeção cartográfica a coordenada geográfica de: GCS_WGS1984;

- O datum de coordenadas planas foi de: WGS 1984 UTM Zone 22S (esta é a projeção plana da região da área de estudo).

Em seguida foram extraídas as curvas de nível de forma automática utilizando-se da ferramenta contour na suíte surface do Arc toolbox. Na janela que se abre desta ferramenta, selecionou-se a imagem de radar (na pasta onde está localizado o arquivo) em Input raster. No item contour interval, colocou-se o intervalo de equidistância das curvas, neste caso, 5 metros. No item Output polyline features indicou-se a saída do arquivo e clicou-se em ok para gerar automaticamente as curvas.

\subsection{Extração da rede de drenagem}

A drenagem foi extraída de forma automática, utilizando-se da caixa de ferramentas Arc toolbox, na suíte Spatial analyst tools, em ferramentas do Hidrology, realizou-se a sequência:

- Flow Direction (direção do fluxo): esta ferramenta gera um arquivo raster contendo a direção de cada fluxo na célula (pixel), levando em consideração oito pixels vizinhos ao pixel central e calculando a diferença de elevação entre eles. A finalidade é atribuir um número de elevação dado por uma componente numérica, através do MDE gerado, possibilitando identificar o caminho do fluxo da água na imagem em pixel.

- Flow Accumulation (acumulação de fluxo): esta ferramenta indica a direção de acúmulo de fluxo de água criado pelo DEM anterior (Flow Direction).

Em cada etapa criada, um arquivo MDE novo foi gerado, constituindo o produto da ferramenta anteriormente usada.

- Álgebras de Mapas (raster calculator): esta ferramenta auxilia na delimitação da densidade de drenagem que será criada. Ela serve como ferramenta limiar para estabelecer quantos pixels adjacentes deve formar a rede de drenagem. Optou-se pelo valor de 500 pixels. Porém outra configuração pode ser feita no valor dos pixels, ficando a cargo do pesquisador. Através da função CON (CONDITIONAL) elaborou-se uma condição lógica que retorna um resultado. A condição para criar o limiar filtra apenas os pixels significativos utilizando o arquivo
(MDE) raster Flow Accumulation. Dentro da caixa da ferramenta raster calculator digitou-se: Con("FLOW_ ACCUMULATION.tif" > 500).

- Stream to Feature (Feição para fluxo): com esta ferramenta do hidrology é gerada a rede de drenagem final, utilizando-se do raster elaborado na etapa anterior, além do raster flow direction. Com o uso do mesmo arquivo flow direction gerou-se as bacias hidrográficas de cada rio, usando-se a ferramenta basin na suíte hidrology.

As janelas que se abrem quando selecionado cada ferramenta são de fácil entendimento, necessitando apenas da inserção de um arquivo anteriormente gerado (os itens são extremamente inteligíveis indicando qual arquivo deve ser selecionado).

\subsection{Mapa de Declividade e elaboração do mapa de ICR}

Para a elaboração do mapa de declividade das bacias hidrográficas, utilizou-se da ferramenta slope na mesma suíte - surface. Nesta ferramenta selecionou-se o MDE (modelo digital de elevação) original, indicando a saída do arquivo (na pasta a ser salvo) e determinou as unidades de mensuração, se em graus ou porcentagem, neste caso, porcentagem, clicou-se em ok.

Ao gerar o mapa de declividade através da ferramenta slope transformou-se o MDE de declividade, em pontos, através da ferramenta raster to point, existente na suíte conversion tools. Selecionou-se a ferramenta from raster, em seguida clicou-se em raster to point, inserindo-se os itens solicitados nas janelas (inteligíveis).

Em seguida, selecionou-se o estimador de densidade Kernel, na suíte - Spatial Analyst tools - ferramenta Kernel density. Esta ferramenta geoestatística (Kernel density) existente no software de mapeamento tem a função de gerar as áreas amostrais de maior e menor intensidade de um fato ou fenômeno. Neste caso, representa as áreas de maior dissecação e menor dissecação do relevo, a partir da disposição dos pontos gerados pelo mapeamento de declividade da etapa anterior.

\section{4 Álgebra de mapas}

Seguindo a sequência metodológica, realizou-se a álgebra de mapas para a normalização e obtenção dos valores de ICR locais (SAMPAIO e AUGUSTIN, 2014b). Como o primeiro raster de entrada foi a imagem ASTER GDEM de 
resolução de 30 m, o mapa produzido pelo algoritmo Kernel density teve de ser dividido em uma expressão lógica, na ferramenta raster calculator.

Foi atribuído um valor de número de pixels (neste trabalho o valor foi de 1111) que representa uma área referente a região que abrange as morfologias dentre um raio mínimo selecionado, neste caso $564 \mathrm{~m} 2$ (SAMPAIO e AUGUSTIN, 2014b). O número de pixels a ser divido na confecção desta etapa, pode variar a depender da resolução da imagem de radar utilizada

Ao final, realizou-se a reclassificação da legenda, através do método estatístico de quantis, existente no software de mapeamento. Para a definição dos limites dos intervalos de classes e o agrupamento destas, selecionou-se layer do MDE final (ICR - local) que representa as unidades de ICR. Com um clique do botão direito do mouse sobre o layer gerado e que representa o MDE de ICR.

Selecionaram-se as seguintes tarefas em sequência: properties - symbology - classified- classify- method - quantile. No item identificado pela palavra "classes" no método quantile definiu-se o número de classes, neste caso, cinco, clicando-se em ok em seguida.

Para os intervalos de classe do mapeamento do ICR levaram-se em consideração as propostas de Sampaio e Augustin, (2014b) para ICR locais e os valores de declividades obtidos através do mapeamento produzido para este trabalho. Além disso, as saídas a campo também possibilitaram a observação das feições existentes e a comparação com a compartimentação obtida a partir da técnica. Os intervalos de valores de ICR utilizados foram:

- plano - valores de ICR abaixo de 2,5,

- suavemente ondulado - valores ICR de 2,5 a 6 ,

- ondulado - valores ICR de 6 a 14,

- fortemente ondulado - valores ICR de 14 a 30,

- escarpado - valores ICR de 30 a 45 e,

- fortemente escarpado - valores ICR acima de 45.

\subsection{Traçado dos lineamentos estruturais}

Para o traçado dos lineamentos que representam as interferências tectônicas existentes no recorte territorial das bacias hidrográficas foi utilizado o mesmo raster ASTER GDEM de $30 \mathrm{~m}$ de resolução. Aplicou-se sobre MDE inicial a ferramenta hillshade (sombreamento) da suíte Spatial Analyst tools-surface.

Foram elaborados diversos arquivos MDE de sombreamento, onde se confeccionou uma variação grande de produtos do sombreamento, através da atribuição de diver- sos valores de azimute e grau de inclinação da luz solar. Esta variação permite visualizar as feições de relevo em posições diferentes de sombreamento. Contribuindo assim, com a observação de um número maior de feições ligadas aos lineamentos facilitando, portanto, o mapeamento e a interpretação.

Na sequência foram demarcadas as linhas estruturais com supervisão dos pesquisadores e com ferramentas de edição de linhas do software de mapeamento na suíte editor. Para a delimitação das linhas estruturais que indicam atividade tectônica levou-se em consideração a orientação da drenagem, formato das vertentes, disposição do conjunto de feições de relevo, análise das curvas de nível, além de sugestões observadas em alguns trabalhos para determinação dos lineamentos (VALERIANO, 2005; FONSECA e CORRÊA, 2011; PALACIOS E VIANA, 2011).

Foram elaborados também dois gráficos de rosetas indicando a frequência de direcionamento dos lineamentos, no recorte que perfaz as bacias hidrográficas do rio Coutinho (o rio Maracujá como é um afluente do Coutinho foi inserido no conjunto de uma roseta) e rio Campo Real. Para a geração das rosetas utilizou-se o software livre Georient 32 v.9, disponibilizado gratuitamente no site: http://www.holcombe.net. au/software/rodh_software_georient.htm.

Também foi consultado mapeamento geológico realizado pelo Serviço Geológico do Paraná (MINEROPAR, 2006; 2015), com a finalidade de relacionar as litologias que afloram nas bacias da pesquisa. Estas informações foram sobrepostas como camadas de layers nos modelos digitais de elevação (MDE) produzidos para este trabalho, a fim de contribuir com a interpretação.

\section{RESULTADOS E DISCUSSÕES}

A região que abrange as bacias hidrográficas dos rios Campo Real, Coutinho e Maracujá, afloram três membros geológicos divididos em duas formações de derrames do tipo tabular, pertencentes ao Grupo Serra Geral, (MINEROPAR, 2015).

O primeiro membro geológico, que sustenta o platô urbano do município é denominado de Guarapuava e pertence a Formação Covó. Este é formado por riodacitos porfiríticos, com características de um subtipo ácido extrusivo, leucocrático a mesocrático em sua coloração. Os riodacitos possuem pelo menos, $30 \%$ de minerais claros (considera-se segundo a bibliografia acima deste valor, rochas ígneas ácidas) e apresenta no geral, quartzo, plagioclásio, com menores 
quantidades de piroxênio, como minerais essenciais (NARDY et. al., 2008; MINEROPAR, 2015).

As rochas (riodacitos) do membro Guarapuava afloram na área de estudo (Fig. 2) na porção S-SE das bacias hidrográficas do rio Coutinho e Campo Real.
Segundo a Mineropar (2006) a região que abrange geomorfologicamente o platô de rochas ácidas (riodacitos) se insere na compartimentação denominada de planalto de Palmas/ Guarapuava. Esta compartimentação de relevo apresenta dissecação considerada baixa pela instituição (op. cit.) e ocupa uma área de $3.266,71 \mathrm{~km}^{2}$.

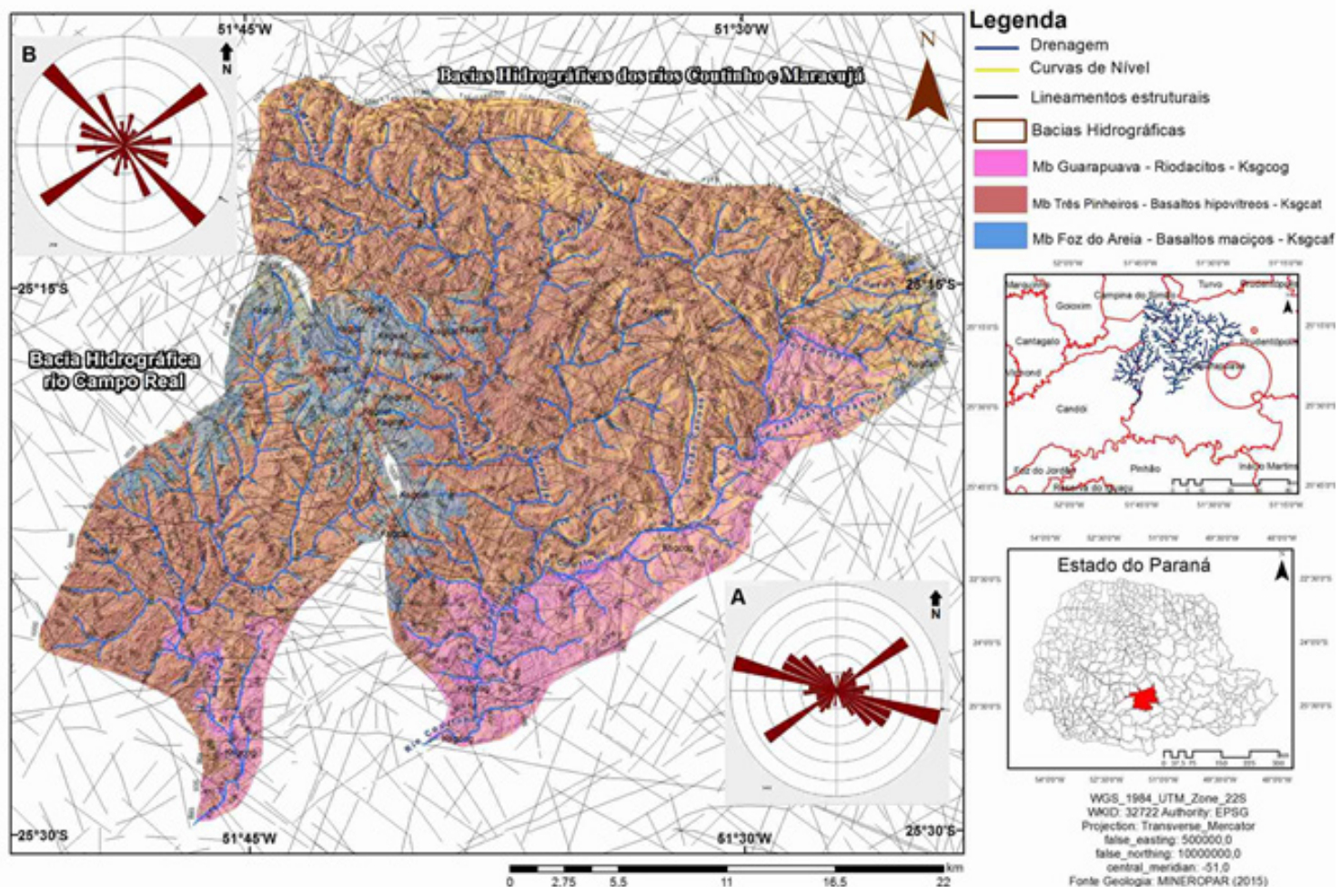

Figura 2. Formações e membros geológicos do Grupo Serra Geral, presentes nas bacias da área de estudo com as rosetas de frequência para cada bacia hidrográfica. Em A as frequências de direcionamento dos lineamentos para a bacia hidrográfica do Rio Coutinho-Maracujá; em B as frequências para a bacia hidrográfica do rio Campo Real. Org. Autores.

Os riodacitos do membro Guarapuava apresentam uma densidade de fraturas de resfriamento e fraturas ligadas a tectônica considerável. Nos exemplares rochosos de leitos, observados em campo, tanto no sentido longitudinal como transversal a corrente (Fig. 3), pode-se constatar que tais estruturas, quando originadas do resfriamento se apresentam alinhadas aos bandamentos de microderrames. Onde ocorre maior concentração de minerais como os piroxênios, que uma vez, intemperizados permitem a presença de pequenas vesículas.

A densidade e disposição de feições estruturais no leito do rio observado, como também em outros de mesma constituição rochosa levantou a hipótese de controle tectônico tanto no direcionamento da drenagem, quanto de influência estrutural na resistência erosiva da rocha em relação à vazão do rio.

As características geomorfológicas das áreas que possuem como rocha subjacente os riodacitos são peculiares.
O relevo apresenta gradiente de 840 metros com altitudes variando entre 520 m (mínima) e 1.360 m (máxima).

No entanto, os afluentes que perfazem a margem esquerda do rio Coutinho e que estão sobre o platô de rochas ácidas (riodacitos) apresentam valores maiores de rugosidade nas áreas de cabeceiras a NE. O relevo neste setor foi delimitado pelo ICR (Fig.4) de ondulado a fortemente ondulado, com vertentes convexizadas e vales ligeiramente encaixados.

Na porção NE da bacia hidrográfica do rio Coutinho há transição litológica, entre dois membros litológicos (Guarapuava e Três Pinheiros - descrição mais abaixo) e entre um terceiro (Foz do Areia - descrição mais abaixo). A ocorrência de lineamentos nesta porção territorial é alta. Observou-se que a drenagem encontra-se condicionada às linhas estruturais existentes influenciando o fluxo da drenagem em inflexões variadas. 


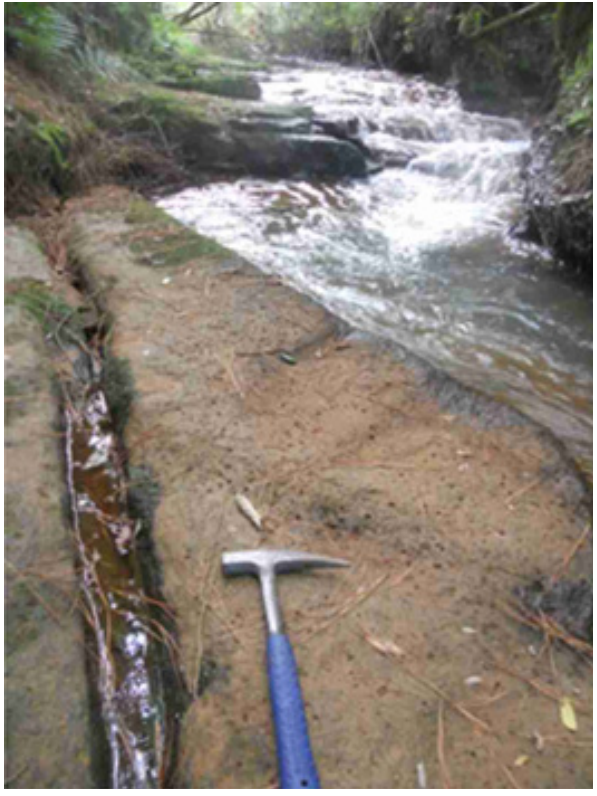

Figura 3. Leito de afluente da margem esquerda do rio Coutinho com vesículas milimétricas e fratura no sentido da corrente fluvial. As fraturas possuem disposição variada levantando a hipótese de controle tectônico no direcionamento da drenagem e de influência na resistência erosiva da rocha. Coordenadas: 451378E; $7199467 \mathrm{~S}$
O mapeamento de declividade produzido (Fig. 5), somado às observações de campo indicaram trechos com alto grau de dissecação vertical. Os valores de declividade mostraram-se acima de 20\%. Acredita-se que o somatório de pelo menos dois fatores: a transição litológica, criando patamares de ruptura e a influencia tectônica estrutural no setor, influa sobre os valores de ondulação mais proeminente mapeado pelo ICR. Observou-se nas saídas a campo que os principais pontos de ruptura e de aumento nos valores de declividade recaem sobre knickpoints ou quedas d'água (cachoeiras) existentes nestas localidades.

Trechos com extensões consideráveis de rápidos e soleiras em degraus também foram indicativos de mudança no declive e de influência na disposição do relevo. A correlação destes trechos com as linhas estruturais delimitadas no mapeamento foram válidas para corroborar também os valores de intensidade zonal do ICR com relevo ondulado a fortemente ondulado.

Em trecho médio do rio Coutinho, também observado em campo nas proximidades da foz do rio Rincão Canoas ocorre uma inflexão de seu curso de NW-SE para NE-SW.

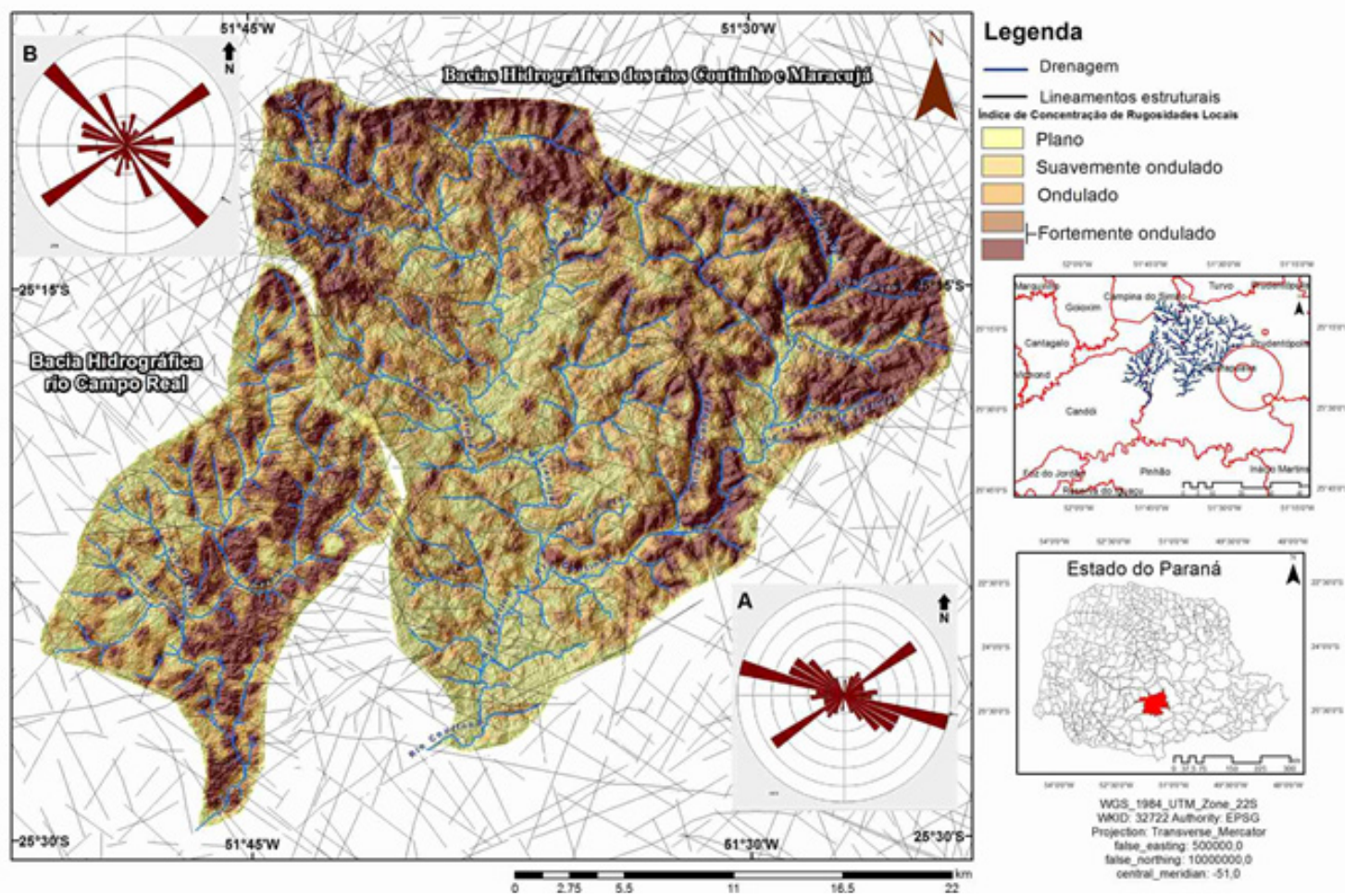

Figura 4. Mapa de índice de concentração de rugosidade para a bacia hidrográfica do rio Campo Real e rios Coutinho-Maracujá. As áreas de maior intensidade de coloração indicam maior rugosidade do relevo (ondulado a fortemente ondulado). A roseta de letra $\mathrm{A}$ indica as frequências dos lineamentos para o conjunto de bacias hidrográficas Coutinho-Maracujá e a letra B para a bacia hidrográfica do rio Campo Real. Org. Autores. 


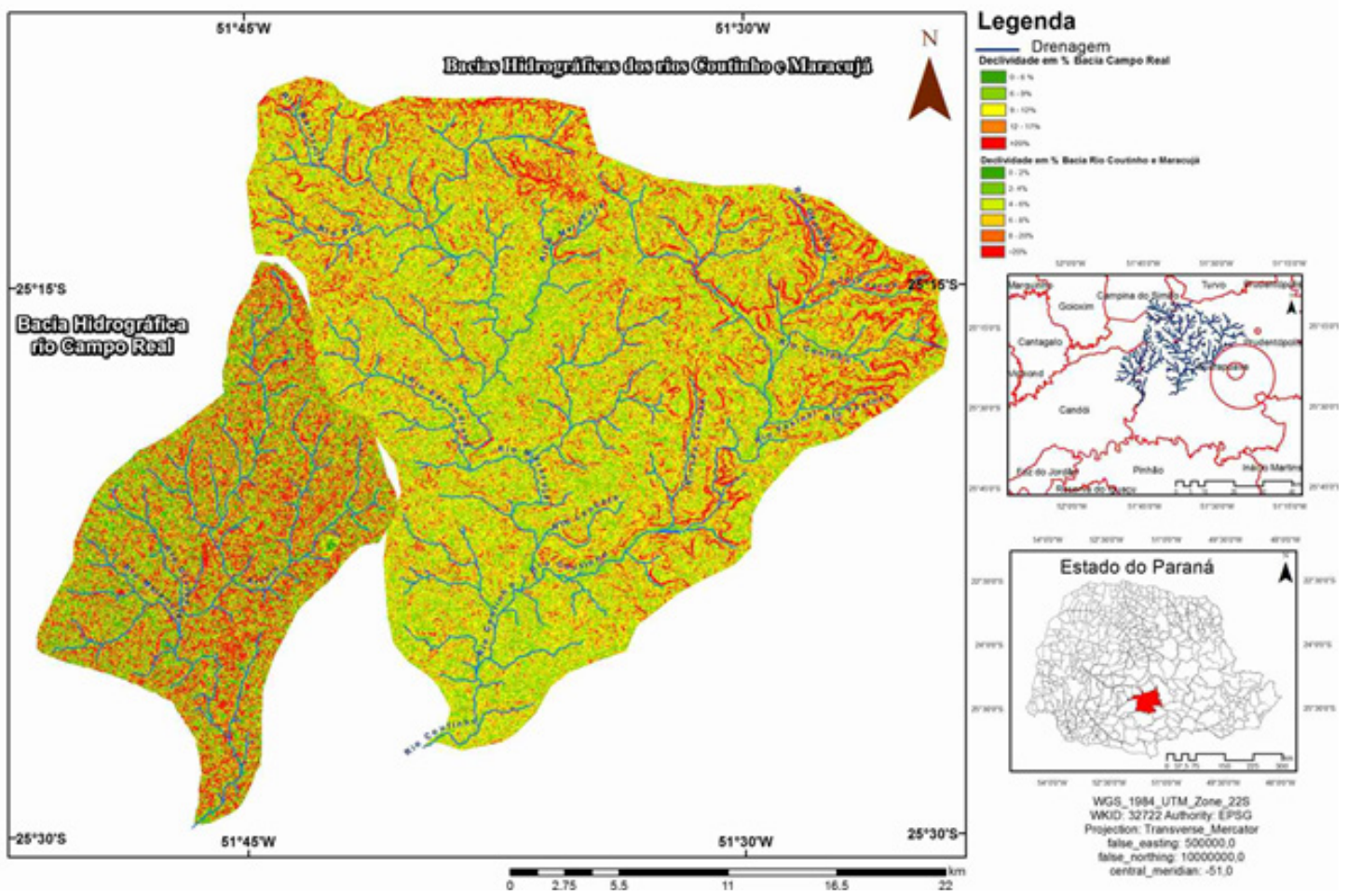

Figura 5. Mapa de declividade produzido para as bacias hidrográficas dos rios Coutinho-Maracujá e Campo Real. Nota-se que os valores de maior declive coincidem também com as zonas de forte ondulação do mapa de ICR. Org. Autores.

Os valores de ICR que indicam relevo ondulado a fortemente ondulado e declividade variando de $8 \%$, a acima de $20 \%$. Neste setor territorial é intensa a presença de lineamentos que condicionam a drenagem a inflexões no sentido mencionado e fornecem desníveis topográficos distintos as vertentes das encostas, além de formar no leito aparentemente, fraturas que não possuem origem no resfriamento rochoso, e sim fraturas com aspectos estruturais.

A feição truncada, indicada pela figura 7 , demonstra como exemplo a interferência dos lineamentos na disposição da drenagem. Neste caso, observou-se que a drenagem encontra-se direcionada sobre os riodacitos em direção a sua foz na direção S-SW, em função do forte condicionamento tectônico no local. As setas amarelas da figura indicam os pontos de origem da feição truncada e os membros geológicos aflorantes no local.

Os vales fluviais, que cortam o platô dos riodacitos, são em quase sua extensão total, vales de constituição rochosa (ou mistos, rochoso-aluvial), alternando sua exposição litológica com trechos de deposição de clastos e mais raramente sedimentação fina nos meandros existentes a jusante.

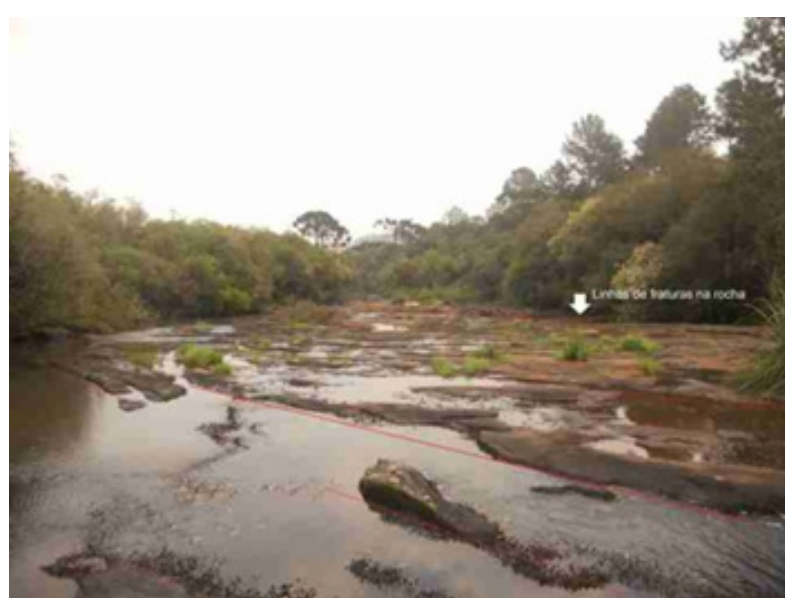

Figura 6. Leito do rio Coutinho, com visão em direção a foz, (riodacitos pórfiros) em período de baixa vazão. O leito possui diversas fraturas alinhadas aos principais lineamentos regionais (NW-SE e NE-SW), visualizados no mapeamento. Não foi possível medir inclinação do mergulho das camadas nem direcionamento geral das fraturas in loco. Org. Autores.

Os vales não localizados nos trechos com ICR, alto ou muito alto, tanto neste setor como nos demais (ondulado ou fortemente ondulado), apresentam-se em formato de "U" e ligeiramente abertos quando em direção as desembocaduras. 

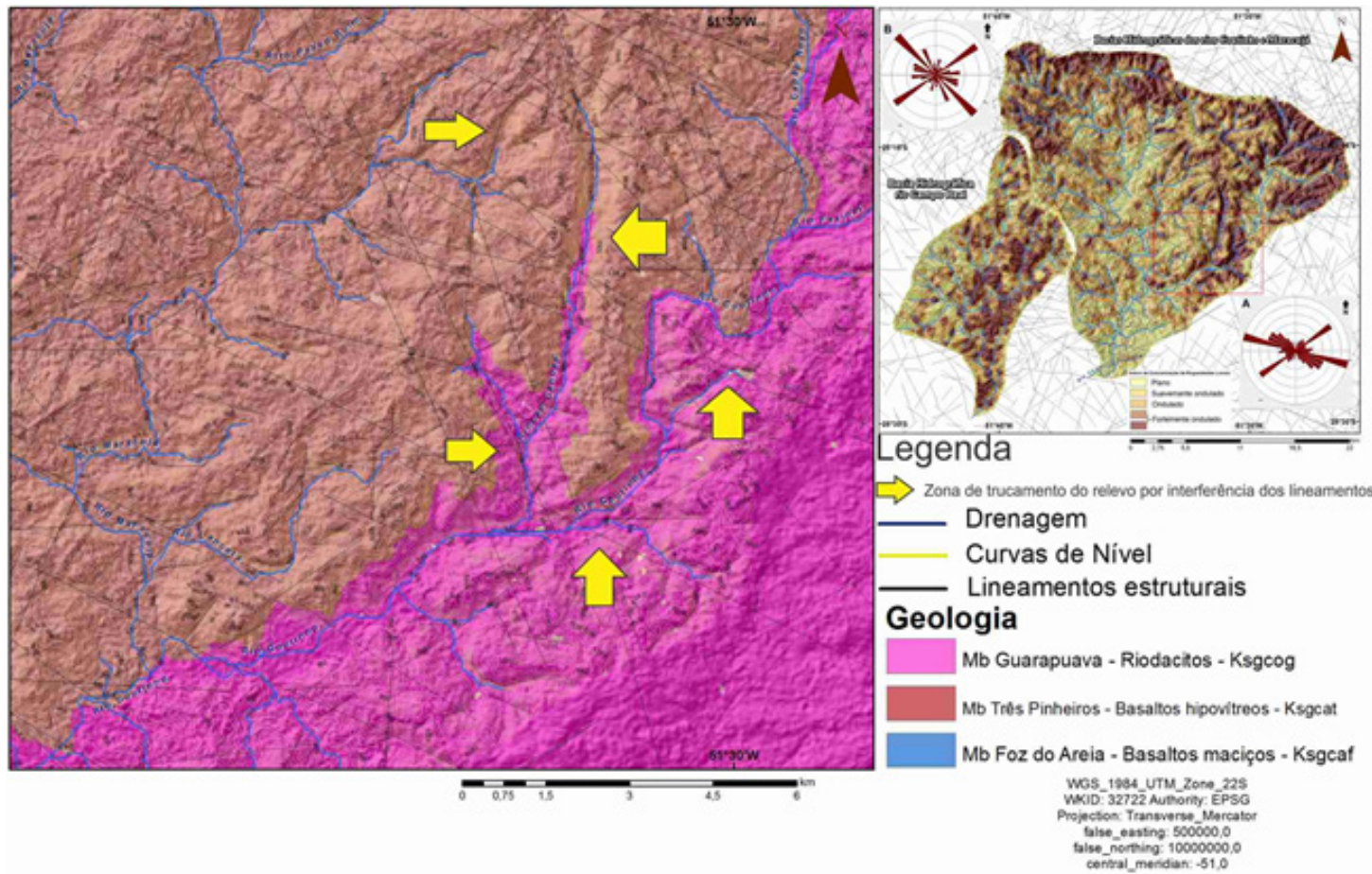

Figura 7. Trecho médio do rio Coutinho onde observou-se uma zona truncada do relevo por incidência de lineamentos de direção variada. Neste setor há transição litológica entre os membros geológicos e valores de fortemente ondulado para o ICR local. Org. Autores.

Os topos aplainados e vertentes retilinizadas do platô central são substituídos por vertentes e topos convexizados no sentido norte das bacias hidrográficas. O ICR indica relevo fortemente ondulado nas áreas de cabeceiras e com a incidência bem marcante de lineamentos de direção E-W, delimitando desníveis topográficos em relação às drenagens com nascentes e cursos em direção contrária do fluxo fluvial das bacias hidrográficas deste estudo.

A partir da margem direita do rio Coutinho afloram as rochas basálticas hipovítreas do membro Três Pinheiros da Formação Candói. O membro Três Pinheiros é formado pelo basalto hipovítreo, caracterizado por derrames toléticos básicos, ricos em TiO2 (NARDY et. al., 2008).

Os hipovítreos sustentam o relevo da área central e porções a N-NW das bacias hidrográfica dos rios Coutinho e Maracujá (principal afluente da margem direita). Além de aflorar em porção central e N-NW da bacia do rio Campo Real. Estes basaltos caracterizam-se por possuir textura afanítica e se apresentarem em tonalidades de cinza-esverdeado a preto (melanocrático). Os minerais essenciais são os plagioclásios e óxidos de ferro, seguidos de quantidade menor de piroxênios (NARDY et. al., 2008; MINEROPAR, 2015).

Os basaltos hipovítreos possuem fraturas conchoidais e disjunção colunar com entablatura em leque, visualizados em cortes observados em campo.
Segundo Arioli et. al. (2008) e Mineropar (2015), a possível presença de água no ambiente de acúmulo dos fluxos de lava, do período de extravasamento forneceu a este membro geológico, a característica hipohialina, o brilho resinoso e as feições em blocos prismáticos. Estas características são fruto do rápido resfriamento de suas estruturas rochosas em tempo geológico pretérito.

Uma destas características pareceu ser relevante e determinante na resistência erosiva frente ao intemperismo e a ação fluvial. A facilidade com que ocorre o destaque dos blocos prismáticos (Fig. 8) e das pequenas colunas de disjunção quando expostos a corrente fluvial chamou a atenção nas observações de campo. A hipótese é que os espaçamentos oriundos da disjunção seja o motivo principal do rápido desgaste do basalto hipovítreo e de sua remoção pela ação fluvial.

A alteração dos hipovítreos é mais proeminente sobre as áreas com alta densidade de fraturas de resfriamento, influenciando não só a resistência da rocha, mas a formação de desníveis topográficos proeminentes, o que pôde ser observado através dos valores de ICR fortemente ondulado no mapa de rugosidade do relevo.

O entablamento em blocos (Fig. 9) torna-se, portanto, uma característica estrutural dos hipovítreos fundamental 
no entendimento da relação resistência erosiva - processos fluviais. Pois a evolução do modelado do relevo será influenciada pelo conjunto de processos intempéricos e fluviais atuantes sobre esta litologia. A maior densidade de fraturas nos hipovítreos é indicativo de uma menor resistência erosiva desta rocha, que apresenta uma constituição mineralógica mais homogênea se comparada aos riodacitos, que possuem heterogeneidade diversa quantos aos minerais e menos fraturas de origem estrutural. Mas em ambas litologias a tectônica incidente parece influenciar a formação de grandes desníveis e formação de maiores declives, seja pontualmente nas calhas fluviais ou no conjunto do relevo.

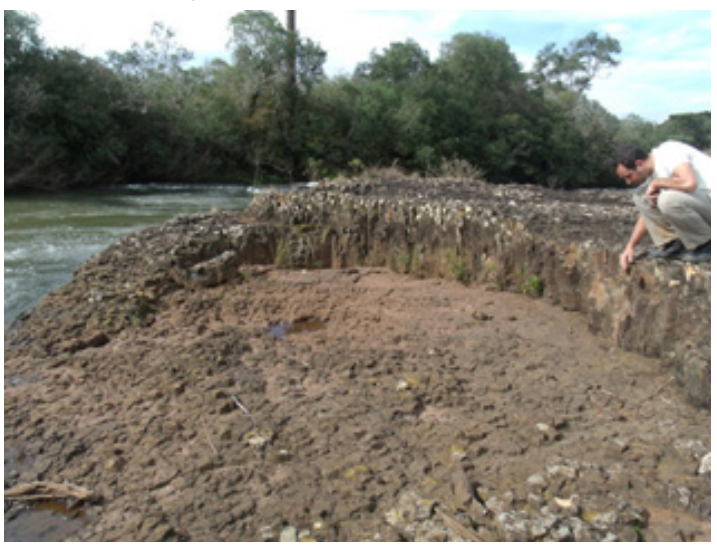

Figura 8. Colunas de disjunção nos basaltos hipovítreos do membro Três Pinheiros do Grupo Serra Geral. Notou-se um padrão na disjunção dos blocos o que facilita a percolação da água e demais processos oriundos da ação fluvial. O espaçamento entre as colunas é milimétrico e em alguns casos centimétricos, fruto do processo de resfriamento litológico pretérito Com o passar do tempo geológico, os pontos de fragilidade dos derrames possibilitaram a formação de fraturas estruturais de disjunção colunar. Coordenadas: 435932E; $7200705 \mathrm{~N}$.

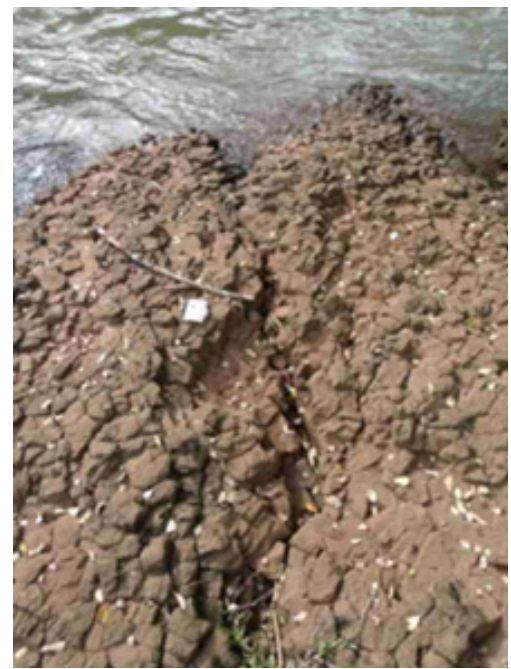

Figura 9. Visão de leito da margem direita do rio Maracujá, onde aflora hipovítreos com entablamento de blocos com disjunção. Notou-se que a facilidade de destacamento dos blocos pela disjunção generalizada promove sua rápida remoção pela ação fluvial. Coordenadas: 436031E; 7200644N.
O direcionamento geral dos lineamentos das bacias do rio Coutinho e Maracujá seguem a tendência regional de NW-SE. Mas com frequências menores de direção NE-SW. As áreas com maiores declives $(>20 \%)$ na região das cabeceiras (limite norte das bacias hidrográficas) apresentam também grande incidência de lineamentos. Os setores de cabeceiras dos rios Maracujá e Coutinho são influenciados, por lineamentos de direção E-W e NW-SE, determinantes nas diferenças topográficas locais.

Nos setores de cabeceiras do Coutinho e Maracujá, bem como de reverso norte das cabeceiras, os basaltos hipovítreos são as rochas que sustentam o relevo. Segundo a Mineropar (2006) a região de reverso das nascentes é denominada de Planalto de Pitanga/Ivaiporã, seus morros (cabeceiras e reverso) apresentam maior amplitude altimétrica e se destacam por feições alongadas com dissecações verticais mais proeminentes, com gradientes altimétricos de mais de $980 \mathrm{~m}$, diferentemente da região central do platô onde os declives são menores que $<6 \%$.

As altitudes variam entre 320 m (mínima) e 1.300 m (máxima), (MINEROPAR, 2006). As formas predominantes são topos alongados, vertentes convexas e vales em formato de 'V', modeladas também em rochas do membro Três Pinheiros do Grupo Serra Geral. O relevo apresenta forte ondulação e trechos pontuais de rupturas de declives ao longo do curso dos rios, fortemente vinculados às falhas e fraturas.

As cabeceiras das bacias dos rios Maracujá e Coutinho, que correm em direção sul (sentido o platô formado pelos riodacitos), encontram-se em cotas altimétricas, relativamente mais baixas que os rios que correm em direção contrária (norte), (Fig. 10).

Aventou-se a possibilidade de um grande basculamento de blocos pela incidência de lineamentos de direção SE-NW e $\mathrm{E}-\mathrm{W}$, que parecem influenciar as cotas topográficas (aumentando a dissecação, pela observação do ICR) das nascentes dos rios que drenam em direção ao platô dos riodacitos (sul). $\mathrm{Na}$ porção NE, onde estão localizados dois afluentes do rio Coutinho (rios Fueros e Gramados), a distinção de valores de cotas topográficas das nascentes e de reverso corrobora a hipótese de influência dos lineamentos no desnível do relevo. O contato direto entre os derrames de basalto maciço (membro Foz do Areia) e basalto hipovítreo (membro Três Pinheiros), também tornar-se uma componente relevante na interpretação do desnível topográfico e nos valores de ICR fortemente ondulado observados no setor.

O diferencial litológico presente na região acaba por fornecer diferentes características de resistência erosiva entre cada 
litotipo, e, portanto, fomenta a hipótese da efetividade erosiva da rede de drenagem de forma distinta em cada litologia, influenciando, por sua vez, o relevo.

Outra hipótese recai em uma retomada erosiva em direção as cabeceiras, em função de uma maior dissecação realizada pela rede de drenagem, nos setores que afloram os riodacitos. A maior vazão à jusante, com o aumento da área de drenagem em direção à foz, dissecaria com mais propriedade e rapidez os riodacitos (mais heterogêneos mineralogicamente, mas com menos fraturas) acelerando os processos de erosão nas cabeceiras, mesmo estes (riodacitos), sendo aparentemente, mais resistentes, devido a menor densidade de fraturamento.
Em alguns setores, ocorrem as classes de suavemente ondulado a plano (setores centrais da bacia hidrográfica do rio Maracujá, por exemplo). Quando há incidência de lineamentos ou conjunto deles em áreas de relevo suavemente ondulado, rupturas de declive (knickzone) foram observadas (Fig. 11), sobretudo nas calhas fluviais, aumentando a declividade local $(>20 \%)$.

Os dois grupos rochosos, os riodacitos do membro Guarapuava, e o basalto hipovítreo do membro Três Pinheiros pertencem aos derrames superiores do Grupo Serra Geral. Estes cobrem o membro geológico inferior do Grupo Serra Geral denominado de Foz do Areia (MINEROPAR, 2015), citado acima.

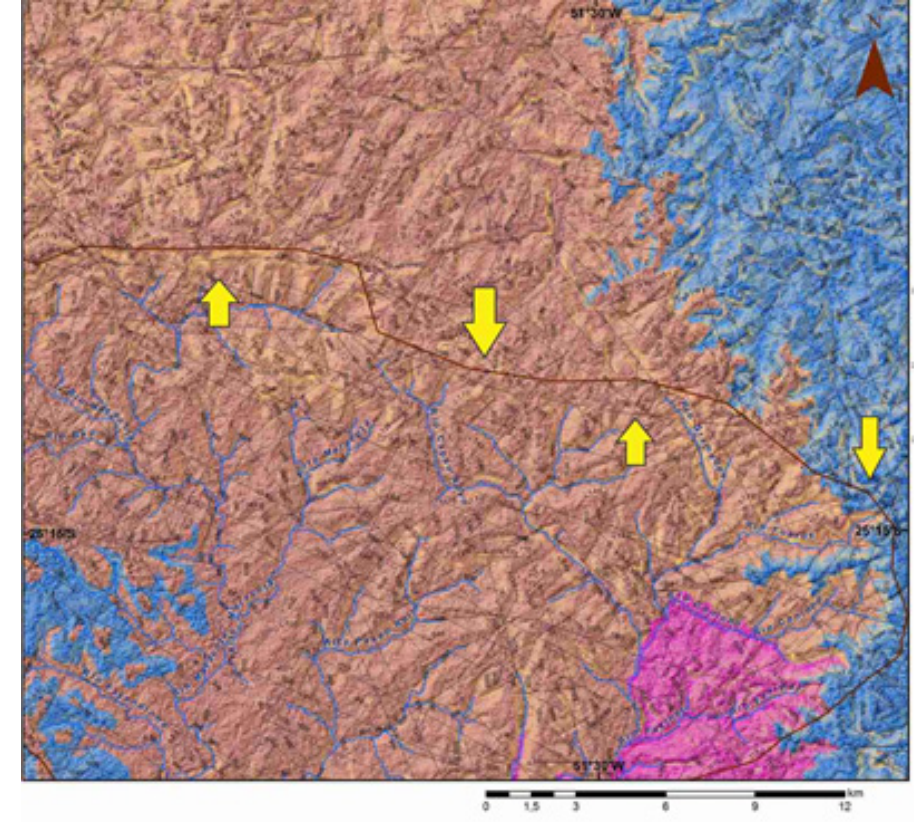

Figura 10. Setor de cabeceiras a norte nos interflúvios da bacia hidrográfica do rio Coutinho. Os valores das cotas altimétricas das nascentes que drenam para o sul são menores daquelas que drenam para o norte. Hipótese de que basculamentos em conjunto forcem a rede de drenagem a correr para o sul e/ou de que a vazão seja mais efetiva sobre os riodacitos promovendo retomadas erosivas nas cabeceiras. Org. Autores.

Contudo, sua a maior heterogeneidade mineral e maior espaçamento (observado em campo) entre as fraturas facilitaria a ação de processos variados de erosão fluvial no destacamento de blocos desta litologia e consequentemente influenciaria no conjunto o modelado do relevo. Esta hipótese, uma vez válida, poderia explicar as cotas topográficas mais baixas das nascentes de N-NE, não levando em consideração, diretamente, os lineamentos incidentes.

Outra constatação observada é que onde a incidência de lineamentos é menor, os valores de ICR tendem a ser de menor ondulação.
O derrame inferior caracteriza-se por um subtipo de basalto maciço com grau de fraturamento bem menor em relação aos hipovítreos e com um grau de coesão dos minerais superior quando comparado com os riodacitos (que é mais heterogêneo aparentemente).

O basalto maciço é afanítico a microfanerítico quanto a sua textura, sua coloração é melanocrática, mas com tons de cinza mais claro, quando em limite com os membros superiores. Os derrames maciços, segundo a Mineropar (2015) apresentam-se em entablamento sigmoidal bem desenvolvidos, sem cloritização ou oxidação visível, em amostra de mão. Possui uma zona vesicular de topo descontínua e frequentemente ausente. 
Este subtipo litológico aflora nas porções leste da bacia do rio Coutinho e nos interflúvios entre as bacias do rio Maracujá e Campo Real, já mencionado anteriormente. Em ambas as localidades os valores de ICR são de ondulado a fortemente ondulado, com declividades superiores a $20 \%$, além da presença dos lineamentos condicionando a topografia e drenagem. Os valores de ICR mais baixos ocorrem em setores com menos incidência de fraturas e falhas e onde não ocorre uma transição litológica clara. Como nos setores mais ao centro da bacia do rio Maracujá e Coutinho, além do extremo oeste da bacia do Campo Real.

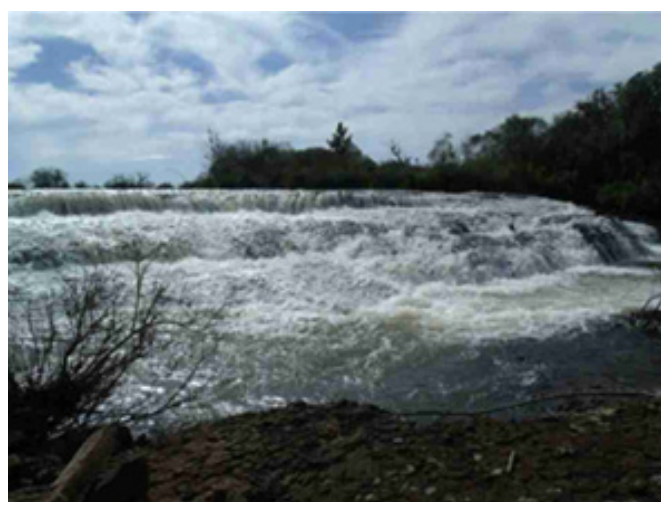

Figura 11. Trecho de ruptura de declive (knickzone) na calha do rio Maracujá, sobre leito de basalto hipovítreo com escalonamento em patamares. Coordenadas: 435932E; 7200705N

As áreas em que aflora e compõem o relevo em cabeceiras NE do rio Campo Real, apresenta seus maiores declives $(>20 \%)$ ao longo da margem esquerda. Onde ocorrem os afloramentos do membro Foz do Areia superam as cotas topográficas locais dos derrames superiores.

No trecho a NE da bacia do rio Campo Real, o membro inferior Foz do Areia e o relevo sobrejacente que o perfaz apresenta densidade alta de lineamentos incidentes. Atribui-se ao trabalho denudativos da drenagem e/ou mesmo o basculamento de blocos pela incidência de lineamentos estruturais, a exposição destes derrames inferiores em superfície, imprimindo assim, uma dissecação alta, localmente, exemplificada pelo ICR local (Fig. 12).

Outra consideração observada é que o basalto maciço (membro Foz do Areia) por ser menos fraturado, em relação ao basalto hipovítreo do membro superior, imprima uma maior força de resistência erosiva, uma vez exposto, frente à drenagem incidente, dificultando por sua vez, a remoção de material, pela rede de drenagem e dificultando o trabalho denudativos da paisagem local.

Na porção sul da bacia do Campo Real, onde afloram os riodacitos, há também ocorrência de valores de ICR ondulado e fortemente ondulado. Neste setor ocorre transição entre os três litotipos citados que congregam o grupo Serra Geral na área de estudo. Acredita-se que a drenagem quando passa a correr sobre os riodacitos, com característica de fraturamento menos densa e mais espaçada (espaço entre as fraturas da rocha) em comparação aos hipovítreos e basaltos maciços, implique uma mudança de resistência erosiva por parte da rocha em relação a drenagem.

Segundo alguns autores consultados (LIMA, 2009, 2010, 2012 e 2014; HOWARD et. al., 1994; SKLAR e DIETRICH 1998; STOCK e MONTGOMERY 1999; WHIPPLE, 2000, 2004; WHIPPLE e TUCKER, 2002; DUVALL et. al., 2004; FINNEGAN et. al. 2005; SNYDER et al., 2000; KIRBY E WHIPPLE, 2001; BROCKLEHURST e WHIPPLE, 2002; KIRBY et al., 2003; WOBUS et al., 2003; VANLANINGHAM, MEIGS e GOLDFINGER 2006; AMBILI e NARAYANA, 2014), o aumento da vazão em trechos a jusante, pode ser inferido como maior potência de escoamento da drenagem e consequentemente, maior poder erosivo, pelo aumento da área de contribuição da drenagem em direção a foz.

Desta forma, o maior poder de incisão em direção à jusante, que neste caso ocorre sobre o relevo sustentado pelos riodacitos e aproveitando-se da maior heterogeneidade mineralógica e espaçamento maior das fraturas da rocha promoveria sobre os riodacitos maior denudação.

\section{CONSIDERAÇÕES FINAIS}

A fácil aplicação, além do simples manuseio da técnica de mapeamento pelo ICR, a partir da delimitação de pontos de intensidade promove um entendimento pleno das áreas de maior ocorrência de dissecação. A junção com dados de sombreamento a partir do MDE da imagem ASTER GDEM, melhorou de sobremaneira a identificação de feições específicas para a análise e interpretação do relevo. Isso demonstrou que o ICR pode ser aplicado em diferentes contextos e relacionado com diversas outras ferramentas de conotação numérica e aplicáveis através dos softwares de mapeamento.

Em relação a pesquisas futuras, pretende-se ainda, debruçar-se mais sobre os processos fluviais mais relevantes existentes nas calhas dos rios. Onde leitos essencialmente rochosos possuem processos fluviais, por vezes, associados a regimes de vazão extrema (quando a vazão alcança o regime de margens plenas ou se excede).

O maior poder de incisão da drenagem, talvez esteja mais atrelado aos processos intrínsecos as estes tipos de leitos e em como estes ocorrem ao longo do tempo. É provável que os processos fluviais mais associados ao regime normal, onde se predomina processos como abrasão tenha uma influencia grande. 


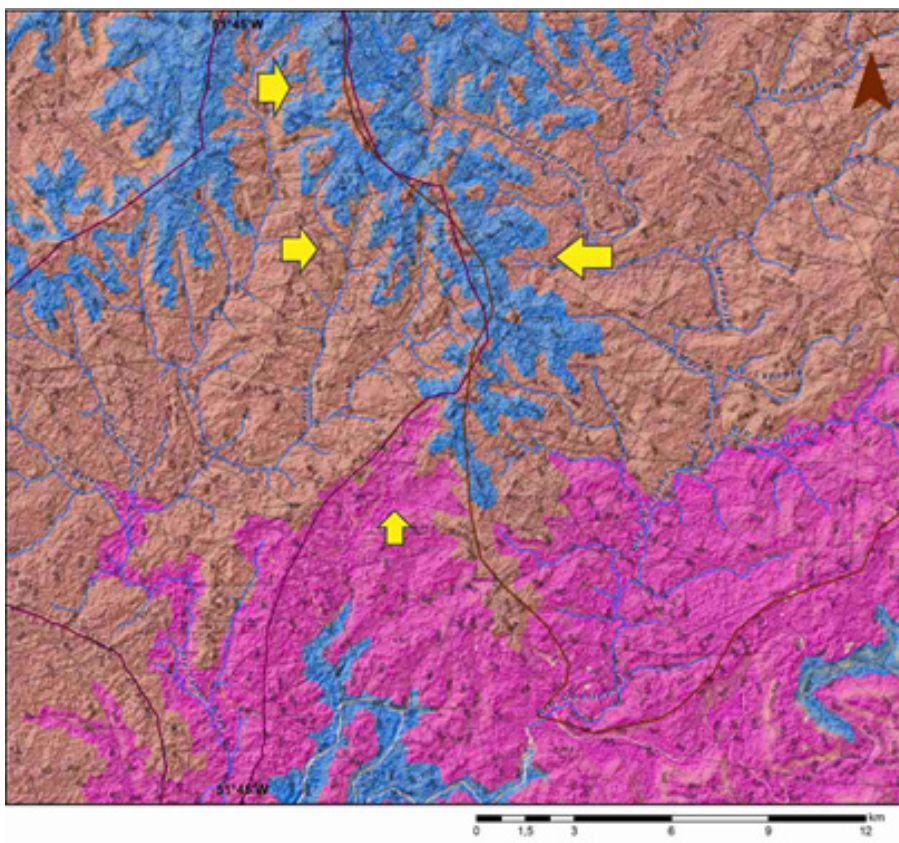

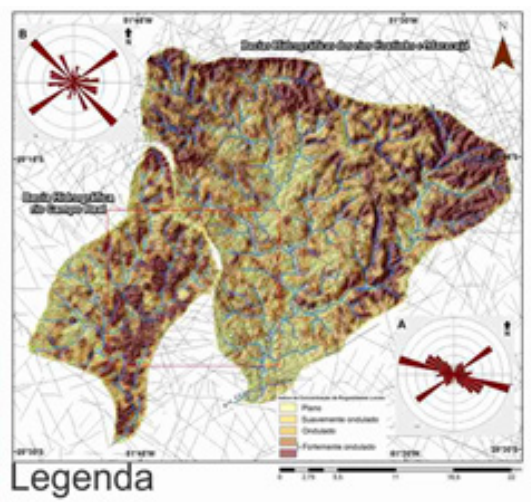

$\Rightarrow$ Zona de trucamento do relevo por interferéncia dos lineamentos Drenagem Curvas de Nivel

Lineamentos estruturais

Geologia

Mb Guarapuava - Riodacitos - Ksgeog
Mb Tres Pinheiros - Basaltos hipovitreos - Ksgcat
Mb Foz do Areia - Basaltos maciços - Ksgca

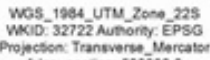

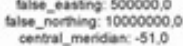

Figura 12. Setor de interflúvio entre os afluentes do rio Campo Real (margem esquerda - NE) e dos afluentes do rio Maracujá (margem direita). Os derrames inferiores do membro Foz do Areia afloram neste setor, com cotas topográficas superiores aos dos derrames superiores do Grupo Serra Geral. Org. Autores.

A intemperização sobre o leito do rio permite posteriormente que os processos como abrasão e arrancamento de porções das rochas, nos momentos de maior vazão permita uma incisão maior sobre o leito. No conjunto da paisagem, estes processos influenciem de maneira mais ou menos específica a depender da localidade e das interrelações existentes entre as diversas características litológicas.

Acredita-se que tais processos fluviais tenham um papel mais que essencial na evolução dos perfis, e também das bacias hidrográficas que os compõem. A denudação da paisagem, entendida a partir dos processos de incisão dos rios, será um próximo passo para uma maior compreensão das respostas geomorfológicas fornecidas pelas transformações sobre os perfis longitudinais e consequentemente no modelado do relevo como um todo.

\section{AGRADECIMENTOS}

Esta pesquisa está sendo financiada pelo CNPq, através de bolsa doutorado (número do processo será alocado quando da aceitação para publicação). Sinceros agradecimentos ao Prof. Dr. Tony Vinicius Moreira Sampaio, professor adjunto da Universidade Federal do Paraná, pelas dúvidas sanadas sobre a configuração do ICR.

\section{REFERÊNCIAS BIBLIOGRÁFICAS}

AMBILI, V; NARAYANA, A.C. Tectonic effects on the longitudinal profiles of the Chaliyar River and its tributaries, southwest India. Geomorphology 217 (2014) 37-47.

ARIOLI, E.E; LICHT, O.A.B; VASCONCELLOS, E.M. G;BONETT, K.L; SANTOS, E.M dos. Faciologia Vulcânica da Formação Serra Geral na Bacia do Paraná. IV Simpósio de Vulcanismo e ambientes associados. Anais... Foz do Iguaçu-PR - 08 a 11/04/ 2008.

CYR, A. J:; GRANGER, D. E.; OLIVETTI, V.; MOLIN, P.; Distinguishing between tectonic and litologic controls on bedrock channel longitudinal profiles using cosmogenic $10 \mathrm{Be}$ erosion rates and channel steepness index. Geomorphology, 209 (2014), pgs. 27-38.

DUVALL, A.; KIRBY, E.; BURBANK, D.W. Tectonic and lithologic controls on channel profiles and processes in coastal California. J. Geophys. Res., Washington, D.C., v. 109F, no. 3, p. 1-18. 2004.

FINNEGAN, N. J.; ROE, G.; MONTGOMERY, D. R.; HALLET, B. Controls on the channel width of rivers: im- 
plications for modeling fluvial incision of bedrock. Geology, v.33, n.3, p.229-232, 2005.

FONSÊCA D. N. e CORRÊAA A. C. de B. Uso de MDE na Extração de Lineamentos para Detecção de Reativações Neotectônicas na Bacia do Rio Preto, Serra do Espinhaço Meridional, MG. XV Simpósio Brasileiro de Sensoriamento Remoto - SBSR. Anais... Curitiba, PR, Brasil, 30 de abril a 05 de maio de 2011, INPE p.3483.

HOBSON, R. D. Surface roughness in topography: quantitative approach. In: Chorley, R.J. Spatial analysis in geomorphology, 225-245. 1972.

HORTON, R. E. Erosional development of streams and their drainage basins: hidrophysical approach to quantitative morphology. Bulletin of the Geological Society of America, v. 56, n. 3, p. 275-370, 1945.

HOWARD, A. D.; DIETRICH, W. E.; SEIDL, M. A. Modeling fluvial erosion on regional to continental scales. J. Geophys. Res., v. 99, no. B7, p. 13971-13986, 1994.

KIRBY, E.; WHIPPLE, K. X. Quantifying differential rock-uplift rates via stream profile analysis. Geology, Boulder, v. 29, p. 415-418, 2001.

LIMA, A. G. Controle geológico e hidráulico na morfologia do perfil longitudinal em rio sobre rochas vulcânicas básicas da Formação Serra Geral no Estado do Paraná. Tese de doutorado. UFSC. Florianópolis - SC. 2009.

LIMA, A.G. (2010). Rios de leito rochoso: aspectos geomorfológicos fundamentais. Ambiência, v.6, p.339 - 354.

LIMA, A. G. Erosão fluvial sobre rochas vulcânicas: algumas inferências a partir de segmentos côncavos de perfis longitudinais. Rev. Bras. Geociências, São Paulo, v. 42, suppl. 1, p. 34-41, 2012.

LIMA, A.G. e Binda. A.L. (2013). Lithologic and structural controls on fluvial knickzones in basalts of the Paraná Basin. Journal of South American Earth Sciences, v. 48, p. $262-270$

LIMA, A.G. (2014). Uso da relação declive-área para avaliação de interferências neotectônicas em perfil longitudinal de rio. Boletim de Geografia, v. 32, n. 2, p. 158-172.
MAULDON, M; DUNNE, W.M.; ROHRBAUGH JR., M.B. Circular scanlines and circular windows: new tools for characterizing the geometry of fracture traces. Journal of Structural Geology, 23 (2001), pgs. 247-258.

MINEROPAR. SERVIÇO GEOLÓGICO DO PARANÁ. O Grupo Serra Geral no Estado do Paraná. Vol. 1 e 2, Curitiba: Mineropar, 2015.

MINEROPAR. SERVIÇO GEOLÓGICO DO PARANÁ. Mapa Geomorfológico do Estado do Paraná. Paraná: Mineropar. 2006.

MINEROPAR. SERVIÇO GEOLÓGICO DO PARANÁ. Mapa Geológico do Paraná. Disponível em: http:/ / www.mineropar.pr.gov.br/modules/conteudo/conteudo. php?conteudo=48. Acesso em 26/10/2015.

NARDY, A. J. R; MACHADO, F.B; OLIVEIRA A.F de. As rochas vulcânicas mesozóicas ácidas da Bacia do Paraná: Litoestratigrafia e considerações geoquímico-estratigráficas. Revista Brasileira de Geociências. São Paulo, 01 -23 de março de v. 38, p. 26-33, 2008.

PAIVA FILHO A. 2003. Estratigrafia e tectônica do nível de riodacitos pórfiros da Formação Serra Geral. Instituto de Geociências e Ciências Exatas, Universidade Estadual Paulista (UNESP), Rio Claro, São Paulo, Tese de Doutorado, 185 p.

PALACIOS, J. R. A.; VIANA, R. R. Detecção e extração de lineamentos locais (sujeitos ao controle estrutural regional) de imagens de relevo, derivadas de dados da srtm. Revista Brasileira de Geofísica, 29(3): 527-533, 2011.

SAMPAIO, T. V. M. Parâmetros morfométricos para melhoria da acurácia do mapeamento da rede de drenagem - uma proposta baseada na análise da Bacia Hidrográfica do Rio Benevente - ES. 2008. Tese de Doutorado. IGC/UFMG. Belo Horizonte, 2008. 147 p.

SAMPAIO, T. V. M., AUGUSTIN, C. H. R. R. Análise das incongruências dos índices de dissecação e rugosidade. VII Encontro Nacional de Geomorfologia, Anais ... Belo Horizonte, 2008a.

SAMPAIO, T. V. M.; AUGUSTIN, C.H.R.R. Índice de concentração da rugosidade: uma nova proposta metodológica para o mapeamento e quantificação da dissecação do relevo como subsídio a cartografia geomorfológica. Revis- 
ta Brasileira de Geomorfologia, v. 15, nº 1 (2014)b.

SAMPAIO, T. V. M.; AUGUSTIN, T. H. R. R. Variáveis auxiliares para o mapeamento da rede de drenagem: correlação espacial entre nascentes, unidades de relevo e litotipos na bacia hidrográfica do rio Benevente-ES. GEOUSP Espaço e Tempo, São Paulo, v. 18, n. 3, p. 624-634, 2014c.

SKLAR, L.; DIETRICH, W. E. River longitudinal profiles and bedrock incision models: stream power and the influence of sediment supply. In: TINKLER, K. J.; WOHL, E.E., (eds.), Rivers over rock: fluvial processes in bedrock channels. American Geophysical Union: Washington, DC, 1998. p. 237-260. (Geophysical monograph 107).

SNYDER, N.P., WHIPPLE, K.X., TUCKER, G.E., MERRITTS, D.J. Landscape response to tectonic forcing: Digital elevation model analysis of stream profiles in the Mendocino triple junction region, northern California. Geol. Soc. Am. Bull. 112, 1250-1263. 2000.

SOUZA, L. F. e SAMPAIO, T. V. M. Aplicação do Índice de Concentração da Rugosidade à identificação de classes de dissecação do relevo: uma proposta de quantificação e automatização em ambiente SIG. III Simpósio Brasileiro de Ciências Geodésicas e Tecnologias da Geoinformação. Anais... Recife - PE, 27-30 de Julho de 2010.

STOCK, J. D.; MONTGOMERY, D. R. Geologic constraints on bedrock river incision using stream power law. J. Geophys. Research, v.104, p. 4983-4993, 1999.

VALERIANO, M.M. TOPODATA: Guia para utilização de dados geomorfológicos locais. INPE: São José dos Campos, 2008), 73p. Disponível em: < http:/ /www.dsr. inpe.br/topodata/ data/guia_utilizacao_topodata.pdf $>$. Acessado em 29/06/2011 (Publicação INPE-15318-RPQ/818.

ZUQUETTTE, L. V.; GANDOLFI, N. Cartografia Geotécnica. São Paulo: Oficina de Texto, 2004. 190 p.

VANLANINGHAM, S.; MEIGS, A.; GOLDFINGER, C. The effects of rock uplift and rock resistance on river morphology in a subduction zone forearc, Oregon , USA. Earth Surf. Processes Landf., Sussex, v. 31, no. 10, p. 1257-1279, 2006.

WHIPPLE, K.X.; HANCOCK, G.S.; ANDERSON, R.S.
River incision into bedrock: mechanics and relative efficacy of plucking, abrasion, and cavitation. Geol. Soc. Am. Bull., v.112, n.3, p. 490-503, 2000.

WHIPPLE, K.X. TUCKER, G.E. Implications of sediment flux dependent river incision models for landscape evolution. J. Geophysical Research, v.107, n.B2, doi: 10.1029/2000JB000044, 2002.

WHIPPLE, K. X. Bedrock rivers and the geomorphology of active orogens. Annual Review Earth Planetary Science, Palo Alto, v. 32, p. 151-185, 2004.

WOBUS, C.W., HODGES, K.V., WHIPPLE, K.X., 2003. Has focused denudation sustained active thrusting at the Himalayan topographic front? Geology, 31, 861-864.

\section{Correspondência dos autores:}

\author{
Diego Moraes Flores \\ e-mail: diegomoraesf@hotmail.com \\ Déborah de Oliveira \\ e-mail: debolive@usp.br
}

Artigo recebido em: 06/06/2016

Revisado pelos autores em: 14/07/2016

Aceito para publicação em: 03/08/2016 